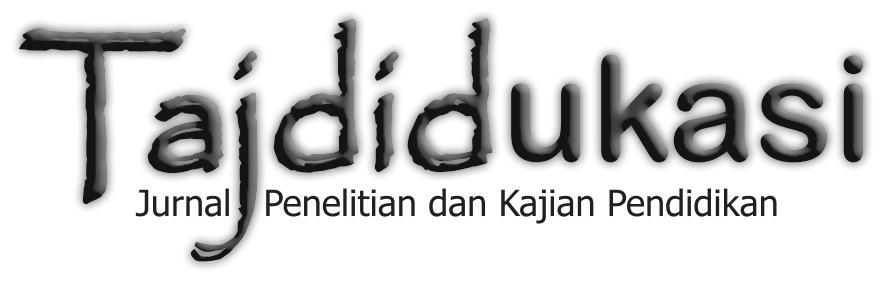




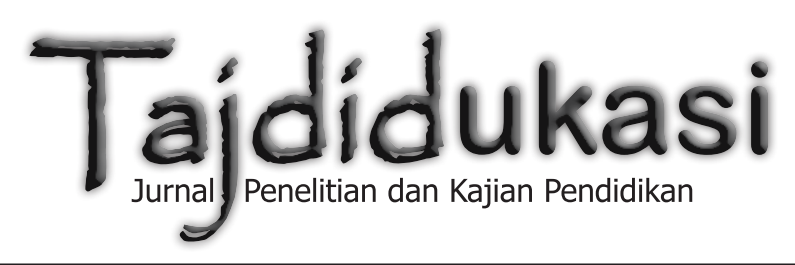

Volume VIII, No. 2, Juli 2018

ISSN: 1979-6943

Tajdidukasi: Jurnal Penelitian dan Kajian Pendidikan merupakan jurnal Penelitian dan Kajian Pendidikan yang berisi Penelitian Tindakan Kelas (PTK) dan Penelitian Tindakan Sekolah (PTS) serta Kajian Pendidikan interdisipliner di Perguruan Tinggi yang diterbitkan Majelis Pendidikan Dasar dan Menengah Pimpinan Wilayah Muhammadiyah Daerah Istimewa Yogyakarta. Artikel hasil PTK dan PTS serta kajian pemikiran pendidikan ditulis oleh para Guru dan Kepala Sekolah serta Dosen dalam mengujicobakan metode dan strategi pembelajaran untuk meningkatkan kualitas pendidikan baik SD/MI, SMP/MTs dan SMA/MA/SMK serta Perguruan Tinggi. Artikel PTK dan PTS fokus pada mata pelajaran di sekolah/madrasah, seperti Ilmu Pengetahuan Alam (IPA), Imu Pengetahuan Sosial (IPS), Matematika, Fisika, Kimia, bahkan teknik, seperti Teknik Mesin, Elektro, Informatika dan lain sebagainya. Sementara itu, artikel Kajian Pendidikan merupakan penelitian interdisipliner dan multidisipliner yang dilakukan Dosen di Perguruan Tinggi terhadap khasanah keIslaman.

Tajdidukasi: Jurnal Penelitian dan Kajian Pendidikan adalah jurnal terbuka yang versi softfile-nya bisa dibaca dan diakses secara gratis, sementara versi print out/ hardcopy dapat diperoleh dengan menghubungi distributor di alamat serial tajdidukasi.ac.id. Sof-file keseluruhan artikel yang diterbitkan dapat diakses melalui Tajdidukasi Open Access Juornal di www.dikdasmenpwmdiy.or.id

Pimpinan Editor
Suyadi, Universitas Ahmad Dahlan (UAD) Yogyakarta, Indonesia

Anggota Editor

Arif Budi Raharjo, Universitas Muhammadiyah Yogyakarta (UMY), Indonesia

Achmad Muhammad, UIN Sunan Kalijaga Yogyakarta, Indonesia

Hendro Widodo, Universitas Ahmad Dahlan (UAD) Yogyakarta

Mundzirin Yusuf, UIN Sunan Kalijaga Yogyakarta, Indonesia

Sumedi, UIN Sunan Kalijaga Yogyakarta, Indonesia

Sukamto, Universitas Muhammadiyah Yogyakarta (UMY), Indonesia

Sumarsono, UIN Sunan Kalijaga Yogyakarta Indonesia

Sarjilah (Lembaga Penjaminan Mutu Pendidikan) Yogyakarta

Fathur Rahman, M.Si., Universitas Negeri Yogyakarta (UNY) Indonesia

\section{Editor Pelaksana}

Suryanto, Universitas Muhammadiyah Yogyakarta (UMY), Indonesia

Suyatno, Universitas Ahmad Dahlan (UAD) Yogyakarta

Farid Setiawan, Universitas Ahmad Dahlan (UAD) Yogyakarta

Alamat Redaksi:

Kantor Majelis Pendidikan Dasar dan Menengah Pimpinan

Wilayah Muhammadiyah D.I. Yogyakarta

J1. Gedongkuning No. 130B Yogyakarta

Kode Pos : 55171

Telephone : (0274) 377078

Facsimile : (0274) 371718

Website : www.dikdasmenpwmdiy.or.id

E-Mail : tajdidukasi@dikdasmenpwmdiy.or.id 


\title{
ACTIVE LEARNING BERBANTUAN FLASHCARD UNTUK MENINGKATKAN HASIL BELAJAR MATEMATIKA PADA MATERI VEKTOR
}

\author{
Andreast Wahyu Sugiyarta \\ SMA Muhammadiyah 3 Yogyakarta \\ E-mail: andreastwahyu@gmail.com
}

\begin{abstract}
Abstrak
Penelitian ini bertujuan untuk menerapkan Active Learning berbantuan flashcard dan untuk meningkatkan hasil belajar pada materi vektor bagi siswa X MIPA 3 SMA Muhammadiyah 3 Yogyakarta. Penelitian ini merupakan Penelitian Tindakan Kelas (PTK). Subjek penelitian ini adalah siswa kelas X MIPA 3 sebanyak 32 siswa. Subyek penelitian ini dipilih karena berdasarkan observasi yang dilakukan guru pada waktu proses pembelajaran, siswa masih sangat kurang aktif. Teknik pengumpulan data dilakukan dengan observasi, tes, dan dokumentasi. Data yang diperoleh dianalisis dengan menggunakan statistika. Hasil penelitian menunjukkan bahwa terjadi peningkatan dilihat dari persentase ketuntasan belajar. Ketuntasan belajar mengalami kenaikan yang signifikan. Pada kondisi awal persentasenya 28,13\% kemudian meningkat pada akhir Siklus I menjadi 40,63\% artinya active learning berbantuan flashcard dapat meningkatkan hasil belajar siswa namun masih belum mencapai target yaitu $80 \%$ sehingga dilanjutkan pada Siklus II. Diakhir Siklus II terjadi lagi peningkatan yang lebih siggnifikan lagi menjadi $100 \%$ artinya active learning berbantuan flashcard sangat cocok diterapkan untuk meningkatkan hasil belajar. Dengan demikian dapat disimpulkan bahwa active learning berbantuan flashcard dapat meningkatkan keaktifan dan hasil belajar siswa. Model pembelajaran ini dapat dijadikan alternatif bagi para guru matematika dalam melakukan kreatifitas pembelajaran di kelas.
\end{abstract}

Kata Kunci: Active Learning, Media Flashcard, Hasil Belajar, Materi Vektor

\section{A. PENDAHULUAN}

Dalam dunia pendidikan, mata pelajaran matematika telah diperkenalkan kepada siswa sejak tingkat dasar sampai ke jenjang yang lebih tinggi. Guru memegang peranan penting dalam mewujudkan tercapainya tujuan pembelajaran khususnya mata pelajaran matematika. Seorang guru matematika disamping menjelaskan konsep, prinsip, dan teorema, juga harus mengajarkan matematika dengan menciptakan kondisi yang baik agar keterlibatan siswa secara aktif dapat berlangsung.

Berdasarkan observasi di kelas X MIPA 3 SMA Muhammadiyah 3 Yogyakarta pada waktu proses pembelajaran, siswa masih sangat kurang aktif. Saat guru menyampaikan materi pelajaran, siswa banyak yang tidak memperhatikan. Pada waktu siswa mengerjakan soal latihan, guru sesekali menghampiri dan memberi penjelasan kepada siswa yang dirasa kesulitan saat mengerjakan soal akan tetapi siswa kurang aktif dalam menanggapi respon guru. Sehingga, 
pembelajaran di kelas terkesan kurang menyenangkan. Maka guru tidak dapat memberikan pelayanan maksimal kepada siswa secara individual. Hal ini mengakibatkan siswa putus asa dalam menghadapi kesulitan saat mengerjakan tugas, sehingga hasil belajar yang diperoleh kurang maksimal.

Berawal dari permasalahan di atas, penulis tertarik untuk melakukan Penelitian Tindakan Kelas (PTK) dengan menggunakan model pembelajaran Active Learning berbantuan flashcard untuk meningkatkan hasi belajar pada materi vektor. Penelitian Tindakan Kelas (PTK) dengan menggukanan model pembelajaran Active Learning ini sangat penting karena melalui pembelajaran dengan model ini diharapkan hasil belajar matematika terutama materi vektor dapat meningkat.

Tujuan dari penelitian yang sudah dilakukan oleh peneliti adalah untuk menerapkan model pembelajaran Active Learning berbantuan flashcard dalam pembelajaran matematika terutama materi vector sehingga hasil belajar siswa kelas X MIPA 3 SMA Muhammadiyah 3 Yogyakarta dapat meningkat. Berdasarkan tujuan dan latar belakang tersebut, maka hipotesis tindakan dalam penelitian yang sudah dilakukan oleh peneliti adalah melalui model pembelajaran Active Learning berbantuan flashcard, hasil belajar siswa pada materi vektor meningkat.

Menurut Oemar Hamalik (2007: 30) memberikan pengertian tentang hasil belajar adalah sebagai terjadinya peru- bahan tingkah laku pada diri seseorang yang dapat diamati dan diukur bentuk pengetahuan, sikap dan keterampilan. Perubahan tersebut dapat diartikan sebagai terjadinya peningkatan dan pengembangan yang lebih baik dari sebelumnya dan yang tidak tahu menjadi tahu. Hasil belajar merupakan bagian terpenting dalam pembelajaran. Nana Sudjana (2009: 3) mendefinisikan hasil belajar siswa pada hakikatnya adalah perubahan tingkah laku sebagai hasil belajar dalam pengertian yang lebih luas mencakup bidang kognitif, afektif, dan psikomotorik.

Pembelajaran aktif (active learning) adalah proses belajar yang menumbuhkan dinamika belajar yang mengaktifkan siswa dalam proses belajar mengajar (Agus Suprijono, 2009: x). Menurut Hamzah B. Uno dan Nurdin Mohamad (2011: 10) pembelajaran aktif adalah memosisikan guru sebagai orang yang menciptakan suasana belajar kondusif atau sebagai fasilitator dalam belajar, sementara siswa sebagai peserta belajar yang harus aktif. Pembelajaran aktif menurut Bonwell (1991) dalam Panduan Pengembangan Pembelajaran Aktif (Kemdikbud, 2017: 3) adalah merupakan pembelajaran yang melibarkan berpartisipasi siswa dalam proses pembelajara, dimana siswa melakukan suatu kegiatan sesuai dengan tujuan pembelajaran dan tidak hanya pasif mendengarkan penjelasan guru.

Menurut Weltman (2012) dalam Panduan Pengembangan Pembelajaran Aktif (Kemdikbud, 2017: 3) menyata- 
kan bahwa pembelajaran aktif adalah suatu proses belajar di mana siswa secara aktif atau berdasarkan pengalaman belajarnya terlibat aktif dalam proses belajar. Pembelajaran aktif ini berfokus pada tanggung jawab belajar siswa. Selanjutnya, Michel Prince (2004) dalam Panduan Pengembangan Pembelajaran Aktif(Kemdikbud, 2017: 3) mendefinisikan pembelajaran aktif sebagai proses belajar yang melibatkan siswa dalam proses pembelajaran. Pembelajaran aktif menuntut siswa melakukan kegiatan belajar bermakna dan berfikir tentang apa yang mereka lakukan.

Pembelajaran aktif (active learning) mempunyai prinsip-prinsip. Prinsipprinsip persebut menurut Barnes (1989) dalam Panduan Pengembangan Pembelajaran Aktif (Kemdikbud, 2017: 4) menekankan prinsip-prinsip pembelajaran aktif, sebagai berikut (1) Purposive: relevan antara tugas dan tujuan pembelajaran, (2) Reflective: refleksi siswa tentang makna dari apa yang dipelajari, (3) Negotiated: tujuan dan metode pembelajaran disepakati antara siswa dan guru, (4) Critical: siswa menghargai cara-cara yang berbeda untuk mencapai tujuan pembelajaran, (5) Complex: siswa membandingkan tugas dengan kompleksitas yang ada dalam kehidupannya, (6) Situation-driven: kebutuhan terhadap situasi dipertimbangkan dalam rangka membangun tugas-tugas belajar, dan (7) Engaged : tantangan nyata tercermin dalam kegiatan yang dilakukan siswa dalam belajar.

Flashcard adalah kartu kecil yang berisi gambar, teks, atau tanda simbol yang mengingatkan atau mengarahkan siswa kepada sesuatu yang berhubungan dengan gambar, teks, atau tanda simbol. Flashcard biasanya berukuran $8 \mathrm{~cm} \times$ $12 \mathrm{~cm}$, atau dapat disesuaikan besar kecilnya kelas yang dihadapi (Azhar Arsyad, 2011: 119 - 120). Menurut Kasihani (2007: 109), flashcard adalah media pembelajaran dalam bentuk kartu bergambar yang berukuran $25 \mathrm{~cm} \times 30$ $\mathrm{cm}$. Gambar-gambarnya dibuat dengan tangan, foto, atau memanfaatkan gambar/foto yang sudah ada ditempelkan pada lembaran-lembaran flashcard). Dina Indriana (2011: 48) juga mengungkapkan bawa "Flashcard adalah media pembelajaran dalam bentuk kartu bergambar yang ukurannya seukuran postcard atau sekitar $25 \mathrm{~cm} \times 30 \mathrm{~cm}$.

Menurut Dina Indriana (2011: 138), langkah-langkah penggunaan media flashcard yaitu kartu-kartu yang telah disusun dipegang setinggi dada dan menghadap ke siswa, cabut kartu satu per satu setelah guru selesai menerangkan, dan berikan kartu-kartu yang telah diterangkan tersebut kepada siswa yang dekat dengan guru. Mintalah siswa untuk mengamati kartu tersebut, selanjutnya diteruskan kepada siswa lain hingga semua siswa mengamati.

Jika sajian menggunakan cara permainan: (a) letakkan kartu-kartu secara acak pada sebuah kotak yang berada jauh dari siswa, (b) siapkan siswa yang akan berlomba, (c) guru memerintahkan siswa untuk mencari kartu yang berisi gambar, teks, atau lambang sesuai perintah, (d) 
setelah mendapatkan kartu tersebut siswa kembali ke tempat semula/start, (e) siswa menjelaskan isi kartu tersebut.

Vektor adalah suatu ruas garis yang mempunyai panjang dan arah. Di SMA, vektor hanya dipelajari untuk vektor di dimensi 2 dan dimensi 3. Menurut Herynugroho dan Andreast (2017: 30-35) materi tentang vektor adalah sebagai berikut:

\section{a. Vektor di $\mathbf{R}^{2}$ (dimensi dua)}

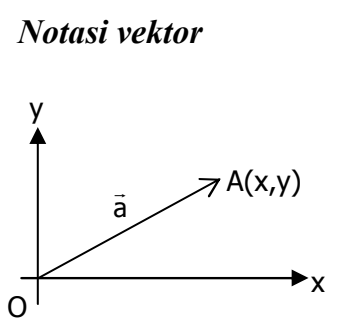

Vektor posisi titik A(x, y) adalah

Gambar 1. Vektor di $\mathrm{R}^{2}$ $\vec{a}=x \vec{i}+y \vec{j}$ dinyatakan dengan komponen $\vec{a}=\left(\begin{array}{l}x \\ y\end{array}\right)$ $\overrightarrow{\mathrm{i}}$ vektor satuan pada arah sumbu $\mathrm{x}$ dan $\vec{j}$ vektor satuan pada arah sumbu y Besar vektor $\vec{a}=\left(\begin{array}{l}x \\ y\end{array}\right)$ adalah $|\vec{a}|=\sqrt{x^{2}+y^{2}}$

Panjang vektor $\overrightarrow{\mathrm{a}}$ adalah $|\vec{a}|=\sqrt{x^{2}+y^{2}}$

\section{b. Vektor di $\mathbf{R}^{3}$ (dimensi 3 )}

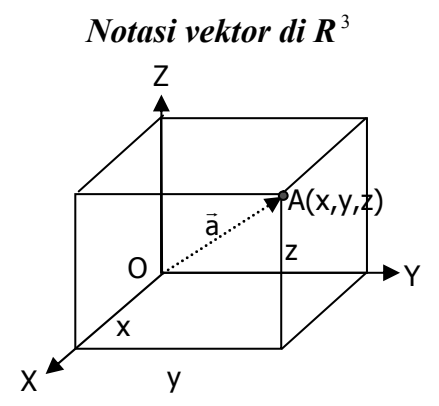

Vektor posisi titik $A(x, y, z)$ adalah $\overrightarrow{O A}=\vec{a}=x \vec{i}+y \vec{j}+z \vec{k}$ Dalam bentuk komponen $\vec{a}=\left(\begin{array}{l}x \\ y \\ z\end{array}\right)$

$\overrightarrow{\mathrm{i}}$ vektor satuan pada arah sumbu $\mathrm{x}$, $\vec{j}$ vektor satuan pada arah sumbu y $\overrightarrow{\mathrm{k}}$ vektor satuan pada arah sumbu z

Gambar 2. Vektor di $\mathrm{R}^{3}$

Panjang vektor $\vec{a}$ adalah $|\vec{a}|=\sqrt{x^{2}+y^{2}+z^{2}}$

Terdapat beberapa penelitian yang relevan dengan Penelitian Tindakan Kelas (PTK) yang sudah dilaksanakan oleh peneliti. Peneitian yang relevan tersebut antara lain sebagai berikut:
Ulva Pratiwi (2015: 491) jurnal dengan judul "Penerapan Model Number Head Together dengan Media Flashcard dalam Peningkatan Pembelajaran Matematika Siswa Kelas IV SD Negeri 
3 Dorowati Tahun Ajaran 2014/2015" menyatakan hasil penelitian menunjukkan bahwa penerapan model number head together dengan media flashcard yang dilaksanakan dengan langkahlangkah yang tepat dapat meningkatkan pembelajaran Matematika siswa kelas IV SD Negeri 3 Dorowati Tahun Ajaran 2014/2015.

Tika Setianingsih (2017: 396) jurnal dengan judul "Penerapan Model Quantum Teachingdengan Media Flashcard dalam Peningkatan Pembelajaran Matematika Tentang Pecahan pada Siswa Kelas IV SD Negeri Tanjungrejo Tahun Ajaran 2016/2017" menyatakan hasil penelitian menunjukkan bahwa penerapan model Quantum Teaching dengan media flashcard dapat meningkatkan pembelajaran Matematika tentang pecahan pada siswa kelas IV SD Negeri Tanjungrejo tahun ajaran 2016/2017.

Yan Aftariawan (2015: 473) jurnal dengan judul "Penggunaan Teknik Make A Match dengan Media Flashcard dalam Peningkatan Pembelajaran Matematika Tentang Bilangan Romawi pada Siswa Kelas IV SDN 2 Kebumen Tahun Ajaran 2014/2015" menyatakan hasil penelitian menunjukkan bahwa penggunaan teknik Make a Match dengan media flashcard dapat meningkatkan pembelajaran Matematika tentang bilangan Romawi pada siswa kelas IV SDN 2 Kebumen.

Berdasarkan uraian di atas, maka dapat disusun kerangka berpikir penelitian seperti dalam Gambar 3 berikut ini:

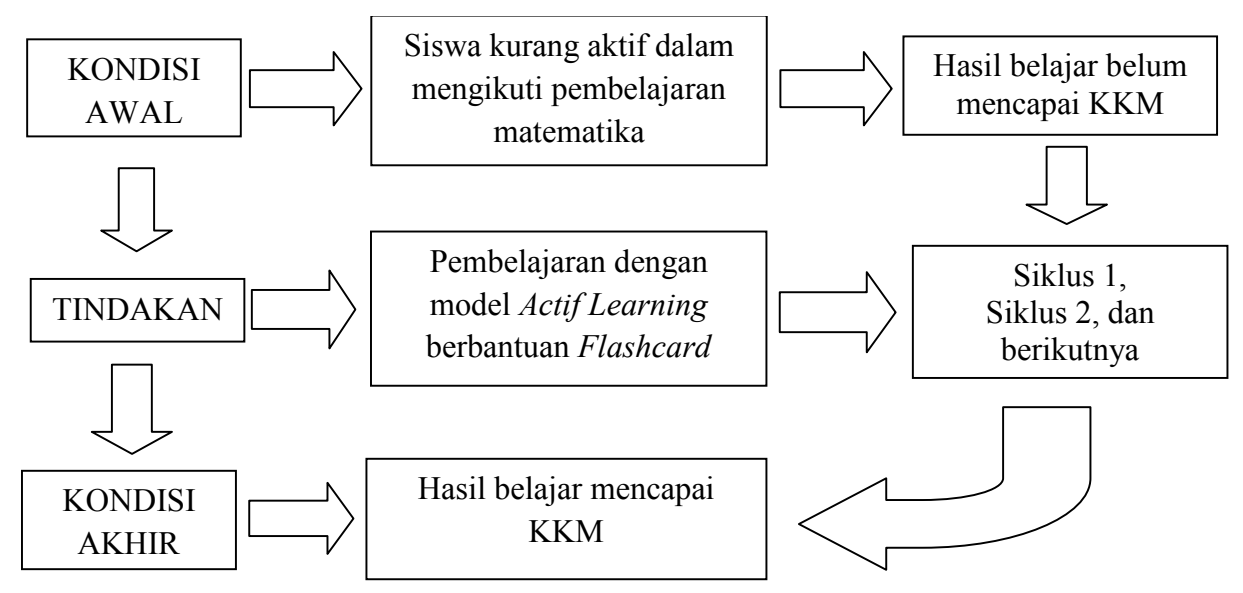

Gambar 3. Skema Kerangka Berpikir

\section{B. METODE PENELITIAN}

Jenis penelitian ini adalah Penelitian Tindakan Kelas (PTK). Menurut Burn (Kunandar, 2010: 44), penelitian tindakan kelas merupakan penerapan penemuan fakta pada pemecahan masalah situasi sosial dengan pandangan untuk meningkatkan kualitas tindakan 
yang dilakukan didalamnya, yang melibatkan kolaborasi dan kerja sama para peneliti, praktisi, dan orang awam.

Subyek penelitian tindakan kelas ini adalah siswa kelas X MIPA 3 SMA Muhammadiyah 3 Yogyakarta Semester Ganjil Tahun 2017/2018 sebanyak 32 anak yang terdiri dari 19 anak laki-laki dan 13 anak perempuan. Siswa kelas X MIPA 3 SMA Muhammadiyah 3 Yogyakarta dipilih sebagai subyek penelitian tindakan kelas ini karena berdasarkan observasi yang dilakukan guru pada waktu proses pembelajaran, siswa masih sangat kurang aktif. Saat guru menyampaikan materi pelajaran, siswa banyak yang tidak memperhatikan. Pada waktu siswa mengerjakan soal latihan, guru sesekali menghampiri dan memberi penjelasan kepada siswa yang dirasa kesulitan saat mengerjakan soal akan tetapi siswa kurang aktif dalam menanggapi respon guru. Sehingga, pembelajaran di kelas terkesan kurang aktif dan menyenangkan. Maka guru tidak dapat memberikan pelayanan kepada siswanya secara individual. Hal ini mengakibatkan siswa putus asa dalam menghadapi kesulitan saat mengerjakan tugas, sehingga hasil belajar yang diperoleh kurang maksimal.

Menurut Mohamad Asrori (2007: 6), Penelitian Tindakan Kelas merupakan suatu bentuk penelitian yang bersifat reflektif dengan melakukan tindakan-tindakan tertentu untuk memperbaiki dan meningkatkan praktik pembelajaran di kelas secara lebih berkualitas sehingga siswa dapat memperoleh hasil belajar yang lebih baik.
Dalam penelitian tindakan kelas ini, peneliti menggunakan bentuk kolaborasi yaitu bekerja sama dengan teman sejawat dalam memikirkan dan menemukan permasalahan yang akan diteliti melalui penelitian tindakan kelas ini. Dengan demikian, peneliti dan teman sejawat dapat saling belajar dan saling mengisi terhadap proses peningkatan profesionalisme.

Pelaksanaan penelitian tindakan kelas ini, peneliti memilih model yang dikemukakan oleh Kemmis dan Mc Taggart (Suharsimi Arikunto, 2007: 16) yang terdiri dari: 1) perencanaan (planning);2) aksi atau tindakan (acting); 3) observasi (obbserving); dan 4) refleksi (reflecting). Keempat komponen tersebut merupakan langkah-langkah sebuah siklus sehingga Kemmis dan Mc Taggart (Suyadi, 2013: 78) menggabungkan tindakan dan pengamatan ini kemudian dijadikan sebagai dasar langkah berikutnya, yaitu refleksikemudian disusun sebuahmodifikasi dalam bentuk tindakan dan pengamatan lagi, begitu juga seterusnya. Model kegiatan penelitian tindakan kelas menurut Kemmis dan Mc Taggart disajikan dalam gambar 4 berikut.

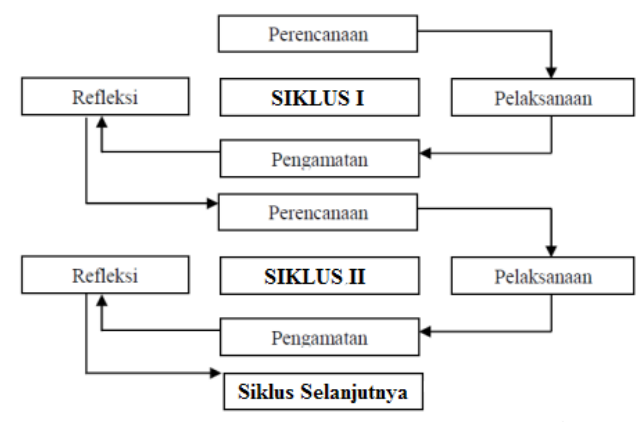

Gambar 4. Model Spiral dari Kemmis dan Taggart 
Teknik pengumpulan data yang dilakukan adalah sebagai berikut.

\section{Pengamatan (Observasi)}

Observasi adalah pengamatan yang dilakukan secara sengaja, sistematis mengenai fenomena sosial dengan gejala-gejala psikis untuk kemudian dilakukan pencatatan (Ronny Hanitiji Soemirto, 1985: 62). Observasi ini akan dilakukan pada awal penelitian. Tujuan dari observasi ini adalah untuk menhgamati situasi, konsisi, serta perilaku siswa pada saat proses pembelajaran berlangsung.

\section{Tes}

Pelaksanaan tes dilakukan untuk memperoleh data mengenai hasil belajar siswa. Tes ini dilakukan untuk penilaian akhir siklus untuk mengetahui perkembangan hasil belajar siswa dari waktu ke waktu. Peneliti membuat tes berupa butir-butir soal yang dapat menguji penguasaan konsep operasi pada vektor. Soal berbentuk uraian dilengkapi dengan pedoman penskoran dan rubrik penilaian.

\section{Dokumentasi}

Dokumentasi ini diperlukan untuk melengkapi data yang diperlukan oleh peneliti serta mendokumentasikan setiap perkembangan yang terjadi setiap kali tindakan baru saja dilakukan.

Penelitian ini sudah dilaksanakan dalam dua siklus mengacu pada model Penelitian Tindakan Kelas yang dikemukakan oleh Kemmis dan Mc Taggart yang menyatakan dalam satu siklus terdapat empat tahapan yaitu 1) peren- canaan (planning); 2) aksi atau tindakan (acting); 3) observasi (obbserving); dan 4) refleksi (reflecting).

Instrumen penelitian merupakan suatu alat atau fasilitas yang digunakan oleh peneliti dalam mengumpulkan data agar pekerjaannya lebih mudah dan hasilnya lebih baik, dalam arti lebih cermat, lengkap, dan sistematis sehingga lebih mudah diolah. Instrumen yang dipakai untuk mengumpulkan data adalah

1. Tes Individu

Instrumen ini digunakan untuk mendapatkan data tentang kemampuan penguasaan konsep operasi vektor. Soal berjumlah dua puluh items berupa soal pilihan ganda dengan lima pilihan jawaban.

\section{Lembar Observasi}

Instrumen ini digunakan untuk mendapatkan data tentang aktifitas siswa pada saat pembelajaran matematika berlangsung dengan menggunakan media flashcard. Adapun aspek yang diamati terhadap aktifitas siswa pada saat pembelajaran matematika berlangsung yaitu tentang keaktifan, kreatifitas, inovasi, dan efektifitas penggunaan media flashcard.

\section{Dokumentasi}

Dokumentasi digunakan untuk mengumpulkan data-data yang terdapat pada Kelas X MIPA 3 SMA Muhammadiyah 3 Yogyakarta. Data tersebut meliputi absensi siswa kelas X MIPA 3 dan hasil evalusai siswa pada mata pelajaran matematika, serta data-data 
lain yang menunjang selama penelitian berlangsung.

Teknik analisis data pada penelitian tindakan kelas ini menggunakan analisis kuantitatif. Analisis ini digunakan untuk menganalisis hasil observasi kegiatan guru dan siswa serta menganalisis hasil belajar siswa. Analisis ini dihitung dengan menggunakan statistika sederhana sebagai berikut.

1. Hasil Observasi Kegiatan Guru dan Siswa

Data yang diperoleh, lalu dianalisis dari pengisisan lembar observasi kegiatan pembelajara di kelas. Hasil observasi ini dibuat dalam bentuk persentase. Kemudian data-data yang diperoleh dari penelitian melalui pengamatan diolah dengan analisis deskriptif untuk menggambarkan keadaan peningkatan pencapaian indikator keberhasilan tiap siklus dan untuk menggambarkan keberhasilan penggunaan media flashcard dikolaborasikan dengan model pembelajaran Active Learning di Kelas X MIPA 3 SMA Muhammadiyah 3 Yogyakarta. Adapun tehnik pengumpulan data yang berbentuk kuantitatif berupa data-data yang disajikan berdasarkan angka-angka maka analisis yang digunakan yaitu prosentase dengan rumus sebagai berikut.

Persentase Keterlaksanaan $=\frac{\text { Skor yang Dicapai }}{\text { Skor Maksimal }} \times 100 \%$

\section{Analisis Hasil Belajar Siswa}

Pada analisis hasil belajar siswa, dihitung nilai rata-rata hasil tes penguasaan konsep operasi vektor dan ketun- tasan hasil belajar siswa dalam bentuk persentase. Berikut adalah rumus perhitungan rata-rata hasil belajar siswa dan ketuntasan hasil belajar siswa.

a. Rata-Rata Hasil Belajar Siswa

Rata - Rata Nilai $=\frac{\text { Total Nilai }}{\text { Jumlah Siswa }} \times 100$

b. Persentase Ketuntasan Hasil Belajar Siswa

Persentase Ketuntasan $=\frac{\text { Banyak Siswa yang Tuntas }}{\text { Jumlah Siswa }} \times 100 \%$

Tingkat keberhasilan penelitian tindakan kelas ini apabila:

1. Meningkatnya kemampuan penguasaan konsep operasi vektor dengan media flashcard dikolaborasikan dengan model pembelajaran Active Learning tiap individu dengan KKM 71. Dan rata seluruh siswa yang mendapatkan nilai tersebut adalah $80 \%$.

2. Adanya peningkatan keaktifan dalam pembelajaran matematika berbantuan flashcard dikolaborasikan dengan model pembelajaran Active Learning setelah melakukan tindakan pada kategori baik dan baik sekali yang mencapai $80 \%$.

\section{HASIL DAN PEMBAHASAN}

\section{Kondisi Awal}

Sebelum dilakukan dintakan perbaikan pembelajaran, terlebih dahulu diadakan pendataan atau pencatatan hal-hal yang dijadikan dasar dari tindakan. Dalam hal ini digunakan perbaikan pembelajaran melalui siklus dalam 
penelitian tindakan kelas. Sebelum dilakukan perbaikan pembelajaran, guru melakukan kegiatan awal berupa siswa membaca secara mandiri materi tentang vektor yang ada pada buku cetak yang digunakan siswa untuk pembelajaran.

Sebagaimana sudah diungkapkan pada rumusan masalah yang diangkat pada penelitian tindakan kelas ini yaitu untuk mengetahui kenaikan hasil belajar siswa, maka dilakukan pengukuran dengan cara siswa mengerjakan berbagai bentuk soal terkait dengan materi vektor yang telah mereka pelajari. Dengan demikian jika hasil belajar siswa kelas X MIPA 3 SMA Muhammadiyah 3 Yogyakarta tinggi, maka dapat dipastikan siswa tesebut telah dapat menguasai materi tesebut demikianpun sebaliknya.

Sebelum dilakukan perbaikan hasil belajar siswa, maka digambarkan kondisi awal (pratindakan) tesebih dahulu yaitu dari hasil penilaian harian KD sebelumnya yang diberikan oleh guru. Ternyata, hasil belajar siswa kelas $\mathrm{X}$ MIPA 3 SMA Muhammadiyah 3 Yogyakarta belum memuaskan. Hal tesebut terlihat dari 32 siswa kelas X MIPA 3 SMA Muhammadiyah 3 Yogyakarta yang mengikuti penilaian harian untuk mengetahui kondisi awal, sebanyak 28,13\% (9 dari 32 siswa) belum mendapatkan nilai yang lebih besar atau sama dengan KKM Sekolah yaitu 71. Berikut adalah table ketuntasan belajar siswa pada kondisi awal.
Tabel 1

Prestasi Siswa Berdasarkan KKM

\begin{tabular}{|l|l|c|c|}
\hline No. & Ketuntasan & Frekuensi & Persentase (\%) \\
\hline 1 & Tuntas & 9 & 28,13 \\
\hline 2 & Tidak Tuntas & 23 & 71,87 \\
\hline \multicolumn{2}{|l|}{ Jumlah } & 32 & 100 \\
\hline
\end{tabular}

Pada tabel 1 di atas, dikemukakan bahwa dari 32 siswa kelas X MIPA 3 SMA Muhammadiyah 3 Yogyakarta, diperoleh ketutasan belajarnya masih $28,13 \%$ terlihat dari nilai setiap siswa masih di bawah $80 \%$. Karena ketuntasan belajar masih $28,133 \%$ artinya masih rendah. Sehingga, perlu dilakukan perbaikan berupa tindakan pada Siklus I untuk meningkatkan nilai rata-rata dan persentase ketuntasan siswa.

\section{Deskripsi Siklus I}

a. Perencanaan

Sebelum pelaksanaan tindakan, terlebih dahulu disiapkan materi atau bahan yang akan digunakan untuk kelancaran penelitian ini. Berikut adalah hal-hal yang disiapkan antara lain telaah materi operasi vektor, membuat Silabus dan Rencana Pelaksanaan Pembelajaran (RPP) dengan menggunakan model Active Learning berkolaborasi dengan media flashcard, membuat flashcard utama berisi materi dan flashcard pendukung berisi soal-soal tentang vektor, dan embuat instrumen penelitian yaitu lembar observasi untuk guru, aktivitas siswa saat mengikuti pembelajaran, dan lembar observasi khusus untuk keterlaksanaan model pembelajaran yang digunakan. 


\section{b. Tindakan}

Tindakan merupakan tahap pelaksanaan mengimplementasikan atau menerapkan rencana yang telah dibuat dan dipersiapkan sebelumnya. Tindakan yang dilakukan adalah pembelajaran matematika pada materi vektor dengan menggunakan model pembelajaran Active Learning berbantuan Flashcard. Tahapan pada tindakan ini merupakan tahapan inti dari proses pembelajaran. Sementara tahapan pelaksanaannya adalah sebagai berikut.

Pada kegiatan pendahuluan, guru memulai kegiatan pembelajaran dengan memberi salam dan meminta salah satu siswa memimpin do'a untuk menumbuhkan rasa iman dan taqwa kepada Tuhan YME, mengkondisikan suasana belajar yang menyenangkan dengan cara meminta siswa untuk mengecek samping kanan kirinya terdapat sampah atau tidak, melakukan presensi, dan meminta siswa untuk menon-aktifkan HP demi kelancaran proses pembelajaran. Guru mendiskusikan indikator pencapaian kompetensi yang sudah dipelajari dan dikembangkan sebelumnya, menyampaikan indikator pencapaian kompetensi yang akan dicapai, menyampaikan garis besar cakupan materi, dan menyampaikan metode pembelajaran dan teknik penilaian yang akan digunakan. Guru pada tahap pendahuluan ini juga membagi siswa menjadi 5 kelompok dengan setiap anggota kelompok berjumlah $6-7$ orang siswa.

Pada kegiatan ini, guru membagikan dua flashcard kepada setiap kelom- pok yaitu flashcard utama \& flashcard pendukung. Flashcard utama berisikan materi pembelajaran yang harus dijelaskan oleh salah satu orang yang ditunjuk sebagai ketua kelompok kepada temanteman satu kelompoknya. Kegiatan ini untuk menumbuhkan pembelajaran aktif sehingga metode Active Learning tampak. Sedangkan Flashcard pendukung berisi tentang persoalan-persoalan yang berkaitan dengan materi yang dipelajari dlam hal ini tentang vektor dan operasinya.

Dalam kegiatan pembelajaran, siswa pertama mengamati permasalahan yang disajikan berkaitan dengan pengembangan persoalan operasi penjumlahan dan pengurangan vektor, perkalian vektor dengan skalar, dan panjang vektor dari Flashcard Utama yang disampaikan oeh ketua kelompok sebagai cerminan dari metode pembelajaran active learning. Selanjutnya guru membagikan flashcard pendukung yang berisi masalah-masalah terkait pengembangan persoalan operasi penjumlahan dan pengurangan vektor, perkalian vektor dengan skalar, dan panjang vektor. Dengan aktif, siswa mengidentifikasi berbagai permasalahan yang berkaitan dengan pengembangan persoalan operasi penjumlahan dan pengurangan vektor, perkalian vektor dengan skalar, dan panjang vektor yang ada pada flashcard pendukung tampa mengabaikan flashcard utama.

Siswa aktif berdiskusi dengan rekan sekelompok berkaitan dengan pengembangan persoalan operasi penjumlahan 
dan pengurangan vektor, perkalian vektor dengan skalar, dan panjang vektor yang disajikan dalam flashcard pendukung dan mengamati materi yang disajikan oleh guru dalam flashcard utama sebagai alur penyelesaian dari permasalahan, dan bertanya dengan guru seandainya ada yang belum dipahami. Siswa menuliskan hasil penyelesaiannya pada kertas yang sudah disediakan guru dan membuat kesimpulan sementara dari hasil diskusi kelompok. Selajutnya, siswa mempresentasikan hasil diskusi kelompok di depan kelas yang sudah dituliskan di kertas yang tesedia, dan kelompok lain memberikan tanggapan dengan mengajukan pertanyaan ataupun memberikan masukkan.

Pada akhir pembelajaran bersamasama dengan guru, siswa membuat rangkuman tentang materi yang sudah diperoleh saat proses pembelajaran. Selain itu, siswa melakukan refleksi dengan cara mengulas kembali materi yang sudah diperoleh selama pembelajaran, sedangkan guru merefleksi diri sendiri seberapa efektif metode dan model pembelajaran yang digunakan dan seberapa banyak materi yang sudah disampaikan ke siswa. Tindak lanjut setelah proses pembelajaran ini adalah siswa diberikan Tugas Testruktur (Proyek). Kegiatan penutup diakhiri dengan meminta salah satu siswa untuk memimpin do'a dan guru mengakhiri dengan salam.

Setelah melaksanakan pembelajaran, kemudian dilakukan penilaian akhir Siklus I dengan tes tertulis. Hasil tes tertulis tesebut adalah sebagai berikut.

Tabel 2

Prestasi Siswa Berdasarkan KKM

\begin{tabular}{|l|l|c|c|}
\hline No. & Ketuntasan & Frekuensi & Persentase (\%) \\
\hline 1 & Tuntas & 13 & 40,63 \\
\hline 2 & Tidak Tuntas & 19 & 59,37 \\
\hline \multicolumn{2}{|c|}{ Jumlah } & 32 & 100 \\
\hline
\end{tabular}

Pada tabel 2 di atas, tertulis bahwa dari 32 siswa kelas X MIPA 3 SMA Muhammadiyah 3 Yogyakarta, diperoleh ketutasan 40,63\%. Ketuntasan tesebut masih di bawah ketuntasan yang ditetapkan pada rumusan masalah yaitu $80 \%$. Sehingga, perlu dilakukan perbaikan lagi pada siklus berikutnya yaitu Siklus II supaya persentase ketuntasan belajar siswa bisa mencapai minimal $80 \%$ sesuai dengan rumusan masalah yang sudah dirumuskan.

c. Observasi

Hasil pengamatan yang dilakukan oleh kolaborator (observer) terhadap pelaksanaan pembelajaran yang dilakukan oleh guru pada Siklus I. Setelah selesai pengamatan, terlihat bahwa ada beberapa aspek yang masih belum terpenuhi saat guru menyampaikan pembelajaran pada Siklus I Pertemuan Pertama. Hal yang belum disampaikan oleh guru pada pertemuan ini antara lain guru belum menyampaikan tujuan pembelajaran secara jelas pada kegiatan pendahuluan. Guru juga belum mengajukan pertanyaan yang membangun siswa untuk mengingat materi yangsudah dipelajari sebelumnya. Selain itu, guru juga belum memberikan umpan balik terhadap pro- 
ses pembelajaran yang sudah dilakukan dan tindak lanjut terhadap siswa. Alokasi waktu pelaksanaan pembelajaran juga menjadi catatan observer yaitu saat diskusi, sebaiknya alokasi waktu dikurangi karena terlalu lama sehinggakegiatan penutup yaitu menyimpulkan sedikit kurang waktu. Namun, secara keseluruhan pembelajaran sudah berjalan dengan baik. Catatan lain yang diberikan oleh observer tentang kegiatan pembelajaran yang dilakukan oleh guru pada Siklus I Pertemuan Pertama ini antara lain pembelajaran sudah berjalan dengan baik terlihat dari pembelajaran yang dilakukan sudah sesuai dengan RPP yang digunakan.

\section{d. Refleksi}

Berdasarkan refleksi yang sudah dilakukan peneliti dengan kolaborator, masih ditemukan beberapa kelemahan yang terjadi pada Siklus I sehingga ratarata nilai siswa belum maksimal yaitu masih di bawah KKM dan ketuntasan belajar siswa juga masih kurang dari $80 \%$. Dari segi keterlaksanaan pembelajaran yang dilakukan oleh guru juga belum mencapai $100 \%$. Selain itu, juga masih terdapat beberapa kekurangan saat penerapan metode active learning berbantuan flashcard. Ketua kelompok seharusnya ditunjuk langsung oleh guru sehingga saat menjelaskan ke teman dalah satu kelompok akan lebih mengena dalam penyampaian materinya.

\section{Deskripsi Siklus II}

a. Perencanaan

Sebelum pelaksanaan tindakan di
Siklus II, terlebih dahulu disiapkan materi atau bahan yang akan digunakan untuk kelancaran penelitian ini dengan memperhatikan beberapa masukan dari kolaborator (observer) pada Siklus I. Berikut adalah hal-hal yang disiakpan antara lain melakukan telaah materi operasi vektor yang belum tesampaikan di Siklus I, membuat Silabus dan Rencana Pelaksanaan Pembelajaran (RPP) dengan menggunakan model Active Learning berkolaborasi dengan media flashcard, merevisi flashcard utama berisi materi dan flashcard pendukung berisi soal-soal tentang vektor, dan membuat instrumen penelitian yaitu lembar observasi untuk guru, aktivitas siswa saat mengikuti pembelajaran, dan lembar observasi khusus untuk keterlaksanaan model pembelajaran yang digunakan.

\section{b. Tindakan}

Tindakan merupakan tahap pelaksanaan yang mengimplementasikan atau menerapkan rencana yang telah dibuat dan dipersiapkan sebelumnya. Tindakan yang dilakukan adalah pembelajaran matematika pada materi vektor dengan menggunakan model pembelajaran Active Learning berbantuan Flashcard. Tahapan pada tindakan ini merupakan tahapan inti dari proses pembelajaran. Sementara tahapan pelaksanaannya adalah sebagai berikut.

Pada kegiatan pendahuluan, guru memulai kegiatan pembelajaran dengan memberi salam dan meminta salah satu siswa memimpin do'a untuk menum- 
buhkan rasa iman dan taqwa kepada Tuhan YME, mengkondisikan suasana belajar yang menyenangkan dengan cara meminta siswa untuk mengecek samping kanan kirinya terdapat sampah atau tidak, melakukan presensi, dan meminta siswa untuk menon-aktifkan HP demi kelancaran proses pembelajaran. Selanjutnya, guru mendiskusikan indikator pencapaian kompetensi yang sudah dipelajari dan dikembangkan sebelumnya, menyampaikan indikator pencapaian kompetensi yang akan dicapai, menyampaikan garis besar cakupan materi, dan menyampaikan metode pembelajaran dan teknik penilaian yang akan digunakan. Guru pada tahap pendahuluan ini juga membagi siswa menjadi 5 kelompok dengan setiap anggota kelompok berjumlah 6 - 7 orang siswa.

Pada kegiatan ini, guru membagikan dua flashcard kepada setiap kelompok yaitu flashcard utama \& flashcard pendukung. Flashcard utama berisikan materi pembelajaran yang harus dijelaskan oleh salah satu orang yang ditunjuk sebagai ketua kelompok kepada temanteman satu kelompoknya. Kegiatan ini untuk menumbuhkan pembelajaran aktif sehingga metode Active Learning tampak. Sedangkan Flashcard pendukung berisi tentang persoalan-persoalan yang berkaitan dengan materi yang dipelajari dlam hal ini tentang vektor dan operasinya.

Dalam kegiatan pembelajaran, siswa pertama mengamati permasalahan yang disajikan berkaitan dengan pengembangan persoalan operasi penjumlahan dan pengurangan vektor, perkalian vektor dengan skalar, panjang vektor, dot product, dan kolinieritas dari Flashcard Utama yang disampaikan oeh ketua kelompok sebagai cerminan dari metode pembelajaran active learning. Selanjutnya guru membagikan flashcard pendukung yang berisi masalah-masalah terkait pengembangan persoalan operasi penjumlahan dan pengurangan vektor, perkalian vektor dengan skalar, panjang vektor, dot product, dan kolinieritas. Dengan aktif, siswa mengidentifikasi berbagai permasalahan yang berkaitan dengan pengembangan persoalan operasi penjumlahan dan pengurangan vektor, perkalian vektor dengan skalar, panjang vektor, dot product, dan kolinieritas yang ada pada flashcard pendukung tampa mengabaikan flashcard utama.

Siswa aktif berdiskusi dengan rekan sekelompok berkaitan dengan pengembangan persoalan operasi penjumlahan dan pengurangan vektor, perkalian vektor dengan skalar, panjang vektor, dot product, dan kolinieritas yang disajikan dalam flashcard pendukung dan mengamati materi yang disajikan oleh guru dalam flashcard utama sebagai alur penyelesaian dari permasalahan, dan bertanya dengan guru seandainya ada yang belum dipahami. Siswa menuliskan hasil penyelesaiannya pada kertas yang sudah disediakan guru dan membuat kesimpulan sementara dari hasil diskusi kelompok. Selajutnya, siswa mempresentasikan hasil diskusi kelompok di depan kelas yang sudah 
dituliskan di kertas yang tesedia, dan kelompok lain memberikan tanggapan dengan mengajukan pertanyaan ataupun memberikan masukkan.

Pada akhir pembelajaran bersamasama dengan guru, siswa membuat rangkuman tentang materi yang sudah diperoleh saat proses pembelajaran. Selain itu, siswa melakukan refleksi dengan cara mengulas kembali materi yang sudah diperoleh selama pembelajaran, sedangkan guru merefleksi diri sendiri seberapa efektif metode dan model pembelajaran yang digunakan dan seberapa banyak materi yang sudah disampaikan ke siswa. Tindak lanjut setelah proses pembelajaran ini adalah siswa diberikan Tugas Testruktur (Proyek). Kegiatan penutup diakhiri dengan meminta salah satu siswa untuk memimpin do'a dan guru mengakhiri dengan salam.

Setelah melaksanakan pembelajaran, kemudian dilakukan penilaian akhir Siklus II dengan tes tertulis. Hasil tes tertulis tesebut adalah sebagai berikut.

\section{Tabel 3}

Prestasi Siswa Berdasarkan KKM

\begin{tabular}{|l|l|c|c|}
\hline No. & Ketuntasan & Frekuensi & Persentase (\%) \\
\hline 1 & Tuntas & 32 & 100 \\
\hline 2 & Tidak Tuntas & 0 & 0 \\
\hline \multicolumn{2}{|c|}{ Jumlah } & 32 & 100 \\
\hline
\end{tabular}

Pada tabel 3 di atas, tertulis bahwa dari 32 siswa kelas X MIPA 3 SMA Muhammadiyah 3 Yogyakarta, diperoleh ketutasan 100\%. Artinya, ketuntasan belajar siswa sudah mencapai lebih dari $80 \%$.

\section{c. Observasi}

Hasil pengamatan yang dilakukan oleh kolaborator (observer) terhadap pelaksanaan pembelajaran yang dilakukan oleh guru pada Siklus II. Berdasarkan pengamatan observer ada satu aspek yang masih belum terpenuhi saat guru menyampaikan pembelajaran pada Siklus II Pertemuan Pertama. Hal yang belum disampaikan oleh guru pada pertemuan ini yaitu guru belum mengajukan pertanyaan yang membangun siswa untuk mengingat materi yangsudah dipelajari sebelumnya. Namun, secara keseluruhan pembelajaran sudah berjalan dengan baik.

Sedangkan hasil observasi pembelajaran yang dilakukan guru oleh observer pada Siklus II Pertemuan Kedua terlihat bahwa semua aspek sudah terpenuhi saat guru menyampaikan pembelajaran pada Siklus II Pertemuan Kedua. Sehingga, persentase keterlaksanaan pembelajaran pada Siklus II Pertemuan Kedua adalah $100 \%$.

\section{d. Refleksi}

Berdasarkan hasil analisis data pada Siklus II di atas, dapat disebutkan setelah pelaksanaan evaluasi akhir terhadap kemamuan siswa terjadi peningkatan rata-rata dan ketuntasan hasil belajar siswa. Selain itu, juga terlihat meningkatnya aktifitas siswa dalam pembelajaran yang didukung oleh meningkatnya aktifitas guru dan ketepatan model pembelajaran yang digunakan yaitu model pembelajaran active learning berbantuan flashcard. 
Pada tahap ini, dapat dijelaskan bahwa pelaksanaan Penelitian Tindakan Kelas (PTK) telah sampai pada hasil yang diharapkan peneliti yaitu siswa lebih aktif dalam mengikuti pelajaran dan hasil belajar siswa meningkat signifikan dengan diterapkannya model pembelajaran active learning berbantuan flashcard dilihat dari rata-rata nilai dan ketuntasan belajar siswa. Berdasarkan hasil diskusi peneliti dengan observer, maka diambil kesimpulan bahwa Siklus II ini dinggap sebagai siklus terakhir karena telah memenuhi ketentuan pada rumusan masalah yang dibuat peneliti.

Berdasarkan uraian di atas, hasil belajar siswa kelas X MIPA 3 SMA Muhammadiyah 3 Yogyakarta mata pelajaran Matematika pada materi operasi vektor dari kondisi awal sampai dengan Siklus II terdapat peningkatan yang siknifikan. Hal tersebut dilihat dari jumlah nilai hasil belajar dalam satu kelas dan rata-rata hasil belajar siswa kelas X MIPA 3 SMA Muhammadiyah 3 Yogyakarta.

Berdasarkan hasil penelitian yang sudah dilakukan peneliti, dapat diungkapkan bahwa hasil belajar siswa kelas X MIPA 3 SMA Muhammadiyah 3 Yogyakarta baik dilihat dari total skor (nilai) dan rata-rata hasil belajar mulai dari kondisi awal, Siklus I, dan Siklus II menunjukkan peningkatan yang signifikan. Dilihat dali total skor (nilai), pada kondisi awal mencapai 1.812, kemudian meningkat pada Siklus I menjadi 2.000, dan di Siklus II naik lagi menjadi 2.769. Sedangkan, jika dilihat dari rata-rata nilai pada kondisi awal hanya mencapai 56,63 , kemudia meningkat pada Siklus I menjadi 65,10, dan pada Siklus II meningkat lagi menjadi 86,42 (Annis Fathimatus Sholihah, 2017: 380). Berikut adalah grafik kenaikan nilai dilihat dari total skor (nilai) dan rata-rata hasil belajar siswa kelas X MIPA 3 SMA Muhammadiyah 3 Yogyakarta.

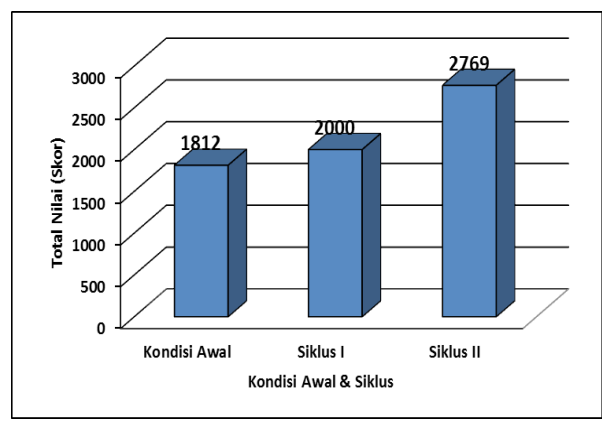

Gambar 5. Grafik Peningkatan Skor dilihat dari Total Nilai

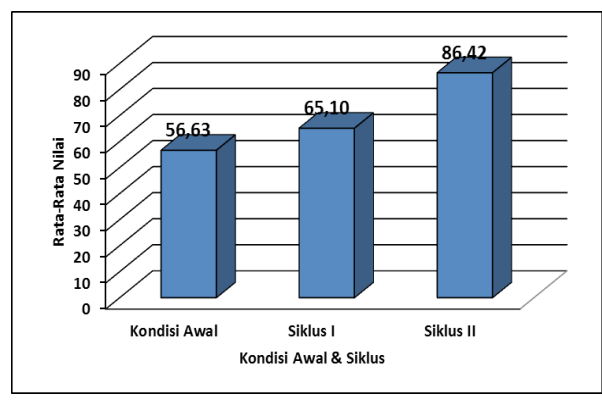

Gambar 6. Grafik Peningkatan Skor dilihat dari Rata-Rata Nilai

Berdasarkan data dan hasil temuan selama proses pembelajaran sampai dengan perbaikan pembelajaran, dapat dinyatakan bahwa model pembelajaran Active Learning berbantuan media Flashcard dapat meningkatkan kualitas proses dan hasil belajar siswa (Fajar 
Ali, 2016: 225). Dari pembahasan hasil penelitian ini, difokuskan pada peningkatan hasil melalui ketuntasan belajar siswa sebagai indikator peningkatan hasil belajar. Hal ini dapat dilihat dari tabel berikut.

\section{Tabel 4}

Rekapitulasi Peningkatan Nilai Siswa Berdasarkan Ketuntasan Belajar Mulai dari Kondisi Awal,Siklus I,dan Siklus II

\begin{tabular}{|c|c|c|c|c|c|c|}
\hline \multirow{2}{*}{ Klasifikasi } & \multicolumn{2}{|c|}{ Kondisi Awal } & \multicolumn{2}{c|}{ Siklus I } & \multicolumn{2}{c|}{ Siklus II } \\
\cline { 2 - 7 } & f & \% & f & \% & f & \% \\
\hline Tidak Tuntas & 23 & 71,87 & 13 & 40,63 & 0 & 0 \\
\hline Tuntas & 9 & 28,13 & 19 & 59,37 & 32 & 100 \\
\hline
\end{tabular}

Tabel di atas menunjukkan bahwa terjadi peningkatan yang siknifikan jumlah siswa yang tuntas dalam belajar (Shonif Muzayyin, 2016: 53). Hal tersebut terlihat dari mulai konsisi awal hanya 9 siswa yang tuntas. Kemudian naik menjadi 13 siswa yang tuntas pada Siklus I dan pada Siklus II naik signifikan menjadi 32 siswa yang tuntas. Berikut adalah grafik dari tabel di atas.

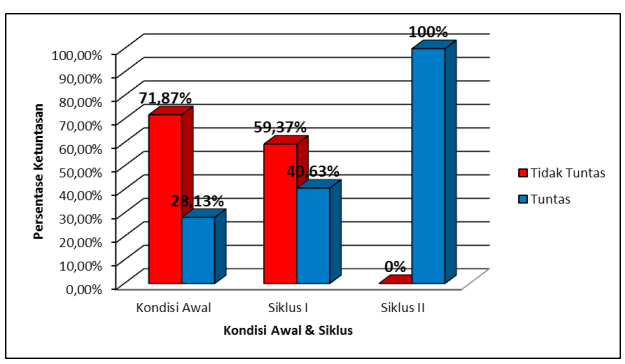

Gambar 7. Grafik Rekapitulasi Peningkatan Nilai Siswa Berdasarkan Ketuntasan Belajar Mulai dari Kondisi Awal,Siklus I,dan Siklus II

\section{KESIMPULAN}

Berdasarkan hasil Penelitian Tindakan Kelas (PTK) dan pembahasan dapat disimpulkan sebagai berikut.

Pertama, model pembelajaran Active Learning berbantuan Flashcard dapat diterapkan untuk meningkatkan hasil belajar pada materi vektor bagi siswa X MIPA 3 SMA Muhammadiyah 3 Yogyakarta. Pada proses pembelajaran, siswa secara aktif melakukan hal-hal yang diperintahkan oleh guru. Terlihat dari diskusi kelompok yang dilakukan siswa saat proses pembelajaran berlangsung. Di setiap kelompok, terdapat satu siswa yang menjadi ketua kelopmok untuk menjelaskan materi dalam flashcard utama dan siswa yang lain aktif memperhatikan dan bertanya tentang materi yang kurang jelas. Dalam kelompok tersebut mereka saling menanggapi dan memberikan masukan. Selain itu, siswa juga aktif dalam menyelesaikan persoalan-persoalan dalam flashcard pendukung yang berisi soal-soal tentang vector. Sehingga, model active learning dengan berbantuan flashcard dapat diterapkan sebagai sebuah model pembelajaran baru dalam dunia pendi- 
dikan khususnya pada pembelajaran matematika.

Kedua, model pembelajaran Active Learning berbantuan Flashcard dapat meningkatkan hasil belajar pada materi vektor bagi siswa X MIPA 3 SMA Muhammadiyah 3 Yogyakarta. Dimana siswa sudah melakukan halhal yang disarankan oleh guru dalam kegiatan pembelajaran baik pada pertemuan pertama atau kedua dengan merode active learning berbantuan flashcard. Siswa sudah aktif mengikuti pembelajaran sampai dengan pengambilan kesimpulan. Data dari observer menunjukkan bahwa $100 \%$ siswa aktif mengikuti pembelajaran. Hal ini juga terlihat dari hasil belajar siswa mulai dari kondisi awal, Siklus I, dan Siklus II. Total nilai (skor), rata-rata nilai, dan persentase ketuntasan belajar siswa kelas X MIPA 3 SMA Muhammadiyah 3 Yogyakarta mengalami peningkatan yang signifikan mulai dari kondisi awal, Siklus I, dan Siklus II. dilihat dari total skor (nilai) dan rata-rata hasil belajar mulai dari kondisi awal, Siklus I,dan Siklus II menunjukkan peningkatan yang signifikan. Dilihat dali total skor (nilai), pada kondisi awal mencapai 1.812, kemudian meningkat pada Siklus I menjadi 2.000, dan di Siklus II naik lagi menjadi 2.769. Sedangkan, jika Dilihat dari rata-rata nilai pada kondisi awal hanya mencapai 56,63, kemudia meningkat pada Siklus I menjadi 65,10, dan pada Siklus II meningkat lagi menjadi 86,42 . Berikut adalah grafik kenaikan nilai dilihat dari total skor (nilai) dan rata-rata hasil belajar siswa kelas X MIPA 3 SMA Muhammadiyah 3 Yogyakarta. Sedangkan ketuntasan belajar juga mengalami kenaikan yang signifikan dimulai dari kondisi awal persentasenya $28,13 \%$ kemudian pada akhir Siklus I mengalami peningkatan untuk persentase ketuntasannya sebesar 40,63\% dan di akhir Siklus II meningkat signifikan lagi menjadi $100 \%$ untuk ketuntasan belajarnya.

Beberapa saran yang dapat peneliti sampaikan berdasarkan hasil Penelitian Tindakan Kelas (PTK) ini dalam rangka membangun semangat dan keprofesionalan dalam pembelajaran matematika SMA kelas X adalah sebagai berikut: bagi guru, hendaknya selalu berkreasi untuk selalu mengembangkan keprofesionalannya dengan cara giat melakukan penelitian terutama Penelitian Tindakan Kelas (PTK) dan bagi peneliti lain yang tertarik dengan Penelitian Tindakan Kelas (PTK) ini dapat mencari model pembelajaran dan media pembelajaran yang lain guna meningkatkan hasil pembelajaran matematika di tingkat SMA supaya lebih baik dari sebelumnya. Sehingga, peneliti lain dapat menghasilkan PTK lain yang lebih baik.

\section{E. DAFTAR PUSTAKA}

Ali, Fajar. 2016. Penerapan Model Problem Based Learning dengan Media Flashcard untuk Meningkatkan Hasil Belajar IPS pada Siswa Kelas IV SD Negeri 4 Tamanwinangun Tahun Ajaran 2015/2016. 
Kalam Cendekia PGSD Kebumen. No 2.1. Vol 4.

Aftariawan, Yan. 2015. Penggunaan Teknik Make A Match dengan Media Flashcard dalam Peningkatan Pembelajaran Matematika Tentang Bilangan Romawi pada Siswa Kelas IV SDN 2 Kebumen Tahun Ajaran 2014/2015. Kalam Cendekia PGSD Kebumen. No 5.1. Vol 3.

Arikunto, Suharsimi. 2007. Manajemen penelitian. Jakarta: Rineka Cipta.

Arsyad, Azhar. 2011. Media Pembelajaran. Jakarta: Rajawali Press.

Asrori, Mohammad. 2007. Psikologi Pembelajaran. Bandung: CV Wacana Prima

Hamalik, Oemar. 2007. Proses Belajar Mengajar. Jakarta:Bumi Aksara.

Herynugroho dan Sugiyarta, Andreast. 2017.Modul Matematika untuk Kelas XII IPA. Yogyakarta: SMA Muhammadiyah 3 Yogyakarta

Indriana, Dina. 2011. Ragam Alat bantu Media Pengajaran. Yogyakarta: Diva Press.

Kemdikbud RI. (2017). Panduan Pengembangan Pembelajaran Aktif. Jakarta: Direktorat Pembinaan SMA.

Kunandar. 2010. Guru Profesional. Jakarta: Rajawali Press.

Muzayyin, Shonif. 2016. Penerapan Metode Discovery dengan Media Kartu Bergambar dalam Peningkatan Kerjasama dan Hasilbelajar IPS Tentang Aktivitas Ekonomi Kelas IV SD Negeri 1 Bumirejo Tahun
2015/2016. Kalam Cendekia PGSD Kebumen. No 1.1. Vol 4.

Pratiwi, Ulva. 2015. Penerapan Model Number Head Together dengan Media Flashcard dalam Peningkatan Pembelajaran Matematika Siswa Kelas IV SD Negeri 3 Dorowati Tahun Ajaran 2014/2015. Kalam Cendekia PGSD Kebumen. No 5.1. Vol 3.

Setianingsih, Tika. 2017. Penerapan Model Quantum Teachingdengan Media Flashcard dalam Peningkatan Pembelajaran Matematika Tentang Pecahan pada Siswa Kelas IV SD Negeri Tanjungrejo Tahun Ajaran 2016/2017. Kalam Cendekia PGSD Kebumen. No 5.1. Vol 5.

Sholihah, Annis Fathimatus. 2017. Penerapan Model Scramble dengan Media Flashcard dalam Peningkatan Pembelajaran IPS Tentang Koperasi pada Siswa Kelas IV SD Negeri Karangkemiri 01 Tahun Ajaran 2016/2017. Kalam Cendekia PGSD Kebumen. No 5.1. Vol 5.

Soemitro, Ronny Hanitiji. 1985. Metodologi Penelitian Hukum. Jakarta: Ghalia Indonesia.

Sudjana, Nana. 2009. Dasar-dasar Proses BelajarMengajar. Bandung: PT Sinar Baru Algensindo.

Suprijono, Agus. 2009. Cooperative Learning Teori dan Aplikasi PAIKEM. Surabaya: Pustaka Pelajar.

Suyadi. 2013. Panduan Guru Profesional Penelitian Tindakan Kelas 
(PTK) dan Tindakan Sekolah (PTS). Yogyakarta: Andi Offset

Suyanto, Kasihani K.E. (2007). English for Young Learners Melejitkan Potensi Anak Melalui English Class yang Fun, Asyik, dan Menarik. Jakarta : Bumi Aksara.

Uno, Hamzah B. dan Mohamad, Nurdin. (2011). Belajar dengan Pendekatan PAILKEM. Jakarta: Bumi Aksara. 